Institute for Research on Poverty

Discussion Paper no. 1219-01

\title{
Welfare Benefits and Female Headship in U.S. Time Series
}

\author{
Robert A. Moffitt \\ Department of Economics \\ Johns Hopkins University \\ E-mail: moffitt@jhu.edu
}

January 2001

The author thanks George Clarke, Jacob Klerman, and Larry Wu for comments, Xue Song and Zhong Zhao for research assistance, and the National Institute for Child Health and Human Development for financial support.

IRP publications (discussion papers, special reports, and the newsletter Focus) are available on the Internet. The IRP Web site can be accessed at the following address: http://www.ssc.wisc.edu/irp/ 


\begin{abstract}
A considerable amount of work has been done on the relationship between AFDC benefits and family structure in the United States. The evidence to date-based on cross-state variation in welfare benefits and family structure, often with state fixed effects—indicates that there is some nonzero effect of those benefits on marriage and fertility, although disagreement remains about the magnitude of the effect. It is undisputed, however, that time-series trends in family structure are not correlated in the direction that the cross-state evidence would suggest, because real benefits have been falling, even relative to wages, in aggregate time series. This paper reexamines the time-series evidence with particular attention to the role of wages in explaining trends in headship, and notes that the correct specification includes male as well as female wages. When both are controlled, welfare benefits have a slight positive impact on female headship even in time series. The results demonstrate the importance of labor market factors in explaining trends in female headship.
\end{abstract}




\section{Welfare Benefits and Female Headship in U.S. Time Series}

Whether welfare benefits affect marriage and fertility decisions of the low-income population has been the subject of much research. The substantial bias in the U.S. welfare system toward femaleheaded families, relative to either married couples or single childless individuals, provides a clear financial incentive for behavior that makes eligibility for welfare benefits more likely or that avoids the loss of eligibility after it has been achieved, such as early nonmarital childbearing, postponement of marriage, divorce, and postponement of remarriage.

The research literature through 1995 has been summarized by Moffitt (1998). The existing literature typically uses data on women in different states with different welfare benefit levels and correlates those benefits with womens' family structure, usually in a regression context controlling for other individual and state-level factors. A number of the studies also include data on individuals in different states over time and examine the correlation between changes in benefit levels and changes in family structure, again typically in a regression framework where state fixed effects are entered. Over 60 separate estimates of this type have been obtained in the literature, according to the Moffitt review. Contrary to some other summaries of the evidence, the review revealed that the central tendency of this cross-sectional evidence is that there are indeed effects of welfare on some aspects of family structure, namely, marriage and nonmarital fertility. However, the review revealed that considerable unexplained dispersion exists in the estimates across studies, leading to some disagreement about the validity of the central tendency. Furthermore, disagreement remains about the magnitude of the effect across studies.

Nevertheless, despite differences, there is widespread agreement in the literature that the timeseries evidence does not support an effect of welfare benefits, since real benefits have been falling for over 20 years—at least in the Aid to Families with Dependent Children (AFDC) program and now the Temporary Assistance for Needy Families (TANF) program—while female headship has been increasing. Moreover, bringing other programs such as Food Stamps and Medicaid into the picture helps 
explain female headship increases in the late 1960s and early 1970s, when those programs were introduced and solidified, but does less well in explaining headship growth in the late 1970s and early 1980s, when growth was still strong. Even the cross-sectional studies that have revealed the largest magnitude of welfare effects do not contravene these time-series correlations, because virtually all of the individual studies, including those with state fixed effects, enter year dummies into their regressions, thereby removing the time-series correlation from the data.

From one perspective, there is no puzzle at all and no contradiction between the cross-sectional and time-series evidence, simply because some forces not present in cross section may have been at work in time series, forces which have pushed female headship up more than the falling welfare benefits have pushed it down. Consequently, it is still possible that female headship might have risen even faster than it did if benefits had not fallen. But this tidy explanation is tautological and lacks credibility unless the other forces can be identified and it can be demonstrated empirically that they caused headship to rise.

This paper is directed at identifying those forces and focuses on labor market opportunity—as proxied by wage rates - as the potential other force pushing female headship rates up. Wages and other measures of labor market potential have played a central role in economic models of the family since the work of Becker $(1973,1981)$ and hence may seem to be an overstudied source of the rise in female headship. However, both the bulk of the theoretical work and most of the traditional empirical work on the subject give too exclusive a role to the female wage rate and too minor a role to the male wage rate. This paper shows that the male wage is an essential part of the story and must be included for the effects of welfare benefits to be estimated correctly.

The role of male wages has not been completely ignored, however, with the work of Wilson (1987) and Wilson and Neckerman (1986) also giving the role of males a central position in explanations of the family structure decisions of disadvantaged women, although much of this work is concerned with labor force and unemployment rates of men rather than with male wages per se. Several cross-sectional 
studies of welfare benefit effects also have controlled for both male and female wages (Danziger et al., 1982; Hoffman and Duncan, 1988; Lichter, LeClere, and McLaughlin, 1991; Lichter, McLaughlin, and Ribar, 1997; Schultz, 1994), generally finding significant effects of both. However, neither the work of Wilson nor the cross-sectional studies are directed at the time-series issue and hence still leave unresolved the inconsistency between the cross-sectional and time-series evidence that is the motivation for this paper.

The results of the analysis indicate that the addition of female wages to a time-series headship equation reverses the sign on the AFDC benefit from negative to positive and, even in specifications where benefit effects are positive to begin with, makes them more positive. Adding the male wage to the equation makes the benefit coefficient even more positive. The results thus offer a possible explanation for the inconsistency between the cross-sectional and time-series correlations. Moreover, for both white and black women it is demonstrated that the decline in the male wage for less-educated men has had more of an effect on headship rates than any upward trend in female wages; thus male wages play a critical role in time-series explanations of headship changes.

The next section of the paper briefly outlines an economic model of female headship which incorporates wage and benefit effects in the simplest possible way. The subsequent, and longer, sections of the paper consider the time-series empirical evidence on wage and benefit effects and whether incorporating wages changes the sign of benefit effects. 


\section{THE ROLE OF WAGES AND BENEFITS IN THE SIMPLE STATIC ECONOMIC MODEL}

Female headship is defined as a family structure in which a woman lives with her own children but without a partner. ${ }^{1}$ The simplest static model, from Becker, defines the marriage decision as based on utility differences between marriage to a particular potential mate or to a random draw from a set of mates with the same characteristics. Conditional on the marriage decision, childbearing decisions are made from standard utility maximization by balancing the utility gains against the marginal costs. ${ }^{2}$ Because female headship is both a marriage and a fertility decision, headship is said to occur when the woman chooses not to marry but to have children. ${ }^{3}$

Assuming that women have individual utility functions containing as arguments leisure, the number of children, other consumption goods, and marriage itself, a model which captures the relevant considerations in minimal form is the following:

$$
\begin{gathered}
\mathrm{K}_{\mathrm{M}=1}=\mathrm{f}\left(\mathrm{W}_{\mathrm{m}}, \mathrm{W}_{\mathrm{f}}, \mathrm{P}_{\mathrm{K}} ; \mathrm{X}_{\mathrm{m}}, \mathrm{X}_{\mathrm{f}}\right) \\
\mathrm{K}_{\mathrm{M}=0}=\mathrm{g}\left(\mathrm{W}_{\mathrm{f}}, \mathrm{P}_{\mathrm{K}}, \mathrm{B} ; \mathrm{X}_{\mathrm{f}}\right) \\
\mathrm{M}^{*}=\mathrm{V}_{\mathrm{M}=1}\left(\mathrm{~W}_{\mathrm{m}}, \mathrm{W}_{\mathrm{f}}, \mathrm{K}_{\mathrm{M}=1} ; \mathrm{X}_{\mathrm{m}}, \mathrm{X}_{\mathrm{f}}\right)-\mathrm{V}_{\mathrm{M}=0}\left(\mathrm{~W}_{\mathrm{f}}, \mathrm{K}_{\mathrm{M}=0}, \mathrm{~B} ; \mathrm{X}_{\mathrm{f}}\right)-\mathrm{C} \\
\mathrm{M}=1 \quad \text { iff } \quad \mathrm{M}^{*} \geq 0 ; \quad \mathrm{M}=0 \quad \text { iff } \quad \mathrm{M}^{*}<0
\end{gathered}
$$

${ }^{1}$ Note that cohabitation, as well as marriage, is excluded in this definition. The census data used below will not permit the separation of cohabitation and female headship, so the distinction is ignored here as well. In addition, nothing in the basic economic model distinguishes cohabitation from marriage, although we will use the word "marriage" instead of "union" because our data will only identify marriage. Also, no distinction is made between female household headship and female family headship, i.e., whether the woman lives in a household of her own or within a larger household, possibly headed by her parents.

${ }^{2}$ It is impossible to do justice to the enormous literature on the economics of marriage and fertility by citation. For marriage, see the work of Becker $(1973,1981)$ and the review paper of Weiss (1997). For fertility, see the papers of Becker (1960) and Willis (1973) and the review paper by Hotz, Klerman, and Willis (1997).

${ }^{3}$ Although the model is neutral on the issue, the empirical evidence suggests that the time-series increase in female headship is more a result of a decline in marriage than an increase in fertility, at least for the white population, and hence a shift of childbearing from married to unmarried women (Smith, Morgan, and KoropeckyjCox, 1996). 
where $M=1$ if the woman is married and $M=0$ if not; $\mathrm{W}_{\mathrm{m}}$ is the male wage rate offered in the market and $\mathrm{W}_{\mathrm{f}}$ is that for the female wage; $\mathrm{P}_{\mathrm{K}}$ is the money price of children; $\mathrm{X}_{\mathrm{m}}$ are characteristics of potential male partners and $\mathrm{X}_{\mathrm{f}}$ are female characteristics; and $\mathrm{B}$ is the welfare benefit. Equations 1 and 2 are demandfor-children equations conditional on marriage. In the married state, both wages have negative price effects and positive income effects, but if women spend more time in childrearing than men, the female wage will more likely have a net negative sign. ${ }^{4}$ In the single state, specialization is more constricted and income is lower, leading to less childbearing than in the married state, but the sign on the female wage is still ambiguous. Welfare benefits, available only if not married, ${ }^{5}$ have a positive effect on childbearing not only from income effects but because they are tied to low levels of work effort.

Equation 3 portrays the utility difference between being married and being single as $\mathbf{M}^{*}$, which is the difference between the female quasi-indirect utility functions $\mathrm{V}_{\mathrm{M}}$, which are in turn conditioned on the pre-optimized number of children, $\mathrm{K}_{\mathrm{M}}$, but not on labor supply or other goods, minus a cost of marriage, $\mathrm{C}$ (search as well as divorce costs). Although the decision problem is portrayed as if it were a two-stage process of initially choosing the number of children a woman would have if she were married and if she were not, and then choosing whether to marry or not on the basis of these values of $\mathrm{K}$ and the other determinants of marriage, this is for expositional purposes only; the model instead considers the decisions to be completely joint.

Wages in the marriage decision again have effects in different directions. An increase in the female wage raises income in both married and unmarried states and hence has no effect on the gain from marriage if utility is raised by the same amount in both, but increases that gain if marriage is a normal good. However, an increase in the male wage only increases utility in the married state, thereby

\footnotetext{
${ }^{4}$ When the quality of children is introduced, even the "income effects" may be negative. See Becker and Lewis (1973) and Willis (1973). See Becker (1965) for the basic household production model.

${ }^{5} \mathrm{We}$ ignore the possibility of welfare benefits for married couples.
} 
increasing the gains from marriage unambiguously. ${ }^{6}$ But the effect of wages on marriage works through the choice of $\mathrm{K}$ as well, and it is here that the classic gains to marriage from specialization and division of labor (i.e., increasing returns) occur in this model. Gains from specialization become greater as the gap between the two wage rates widens, thus giving the wage ratio $\mathrm{W}_{\mathrm{f}} / \mathrm{W}_{\mathrm{m}}$ a central role. ${ }^{7}$ Assuming $\mathrm{W}_{\mathrm{m}}>\mathrm{W}_{\mathrm{f}}$, an increase in $\mathrm{W}_{\mathrm{f}} / \mathrm{W}_{\mathrm{m}}$ will reduce the gains to marriage and marriage rates will fall. Finally, note that welfare benefits appear only in the unmarried state and thus have an unambiguous negative effect on gains to marriage.

Ignoring $\mathrm{P}_{\mathrm{K}}$, the model contains only three key determining variables - the two wages and the welfare benefit (nontransfer, nonwage income is also ignored) - in addition to the exogenous characteristics $\mathrm{X}_{\mathrm{m}}$ and $\mathrm{X}_{\mathrm{f}}$. Defining $\mathrm{F}=1$ if a woman chooses not to marry $(\mathrm{M}=0)$ and to have children $\left(\mathrm{K}_{\mathrm{M}=0}>0\right)$ and $\mathrm{F}=0$ if not—that is, a female headship indicator variable—we will work empirically with the reduced-form expression

$$
\mathrm{E}\left(\mathrm{FlW} \mathrm{W}_{\mathrm{f}}, \mathrm{W}_{\mathrm{m}}, \mathrm{B}, \mathrm{X}_{\mathrm{f}}, \mathrm{X}_{\mathrm{m}}\right)=\mathrm{G}\left[\alpha+\beta\left(\mathrm{W}_{\mathrm{f}} / \mathrm{W}_{\mathrm{m}}\right)+\gamma\left(\mathrm{W}_{\mathrm{m}}+\mathrm{W}_{\mathrm{f}}\right)+\delta \mathrm{B}+\theta \mathrm{X}_{\mathrm{f}}+\eta \mathrm{X}_{\mathrm{m}}\right]
$$

where $\mathrm{G}$ is a probability distribution function mapping the latent index inside the brackets into the unit interval. The two wage rates could be entered separately or in a variety of alternative functional forms but are entered here in ratio and additive form to assist in interpretating effects of specialization, in the case of the ratio, and income effects, in the case of the wage sum. Thus we expect $\beta>0$ and $\gamma<0$. The

\footnotetext{
${ }^{6}$ Although awkward in many respects, this minimal model ignores the male utility gains from marriage. In a more realistic model, both male and female need utility gains to marry, and the chosen leisure, child, and consumption goods are the result of a collective decision mechanism involving both utility functions. However, the model here still allows male leisure and consumption to be in the female utility function. Consequently, complementaries between male and female leisure can give rise to gains from marriage even in this model; indeed, this was the source of gains originally identified by Becker (1973).

${ }^{7}$ The two-stage portrayal of the decision process obscures this specialization effect to some extent, because the joint production of children, leisure, and other consumption is not portrayed in its fully joint form. The way the model is written, the demand-for-children equation (equation 1) already incorporates the specialization decisions in the married state.
} 
price-income distinction is not completely clean since both variables capture different types of price and income effects to some extent; consequently, the expected signs are not completely unambiguous as well.

However, we expect $\delta>0$ unambiguously, and the question in the analysis is whether the omission of the two wage variables from the equation falsely leads to an estimated $\delta<0$, as one observes as a raw correlation in the time-series data.

It is worth emphasizing that in this model the reason that marriage does not occur is because there may be no gains from marriage. Either utility is lowered by being married or the costs of marriage exceed the benefits. This view is at odds with traditional equilibrium models of the marriage market in which equal numbers of men and women always marry, because there are always gains to specialization, even at very low wages. The introduction of costs to marriage, and different utilities in the married and unmarried states, however, implies that the gains to specialization at low wages may be outweighed by negative factors. This model also does not need to rely on sex-ratio explanations to explain nonmarital fertility.

Clearly a model this simple misses many important factors. Other gains to marriage such as those from public goods, from alleviation of imperfect capital markets, and from risk pooling (Weiss, 1997) are ignored. The general equilibrium nature of the marriage market is ignored and consequently so is the importance of imbalance of the two sexes; relatedly, the alternative to marriage is not necessarily being single but rather searching for another partner. Search considerations and matching considerations in the marriage market, and other dynamics, are also ignored in favor of the simplicity of the static model. Whether incorporation of these factors would materially change the expected wage and benefit signs in a female headship equation is unclear, however. 


\section{EMPIRICAL STRATEGY AND DATA}

Given the focus of the analysis on explaining time-series trends in female headship, and also in determining whether the incorporation of wage effects resolves the inconsistency in the sign of welfare benefit effects in past cross-sectional and time-series studies, we follow an empirical strategy of focusing primarily on time-series variation in $\mathrm{F}, \mathrm{W}_{\mathrm{f}}, \mathrm{W}_{\mathrm{m}}$, and $\mathrm{B}$. Cross-sectional variables will be incorporated to some extent by stratifying the analysis by educational level and age but, conditional on education and age, only time-series, aggregate variation in the variables will be utilized. Cross-sectional variation in B (e.g., across geographic areas) is intentionally ignored in favor of a more purely time-series exercise.

We employ data from the March Current Population Survey (CPS) from 1968-1996. From each CPS we select all men and women 18-65 with less than a high school education, and we stratify the sample in each year by birth cohort (grouped into 5-year birth year intervals). We also stratify the sample into two races, white and black, and do not examine other race groups. For each race and each birth cohort group in each year, we calculate a mean male wage rate, a mean female wage rate, and a femaleheadship rate. ${ }^{8}$ The latter is equal to the fraction of women in the group who have children but are not married. The wage rate is the average weekly wage (annual earnings divided by annual weeks of work) in real 1992 dollars over the previous calendar year, taken over workers in that year (tests for selection bias are also conducted). Aggregate national real AFDC, Food Stamp, and Medicaid monthly benefits are available as well, and we compute a weighted sum of the three to arrive at an overall measure of welfare

${ }^{8} \mathrm{We}$ also impose the requirement that each race-cohort-year cell have a minimum of 100 observations, a restriction that is binding only for the black sample. There are 273 cells for the white population and 218 cells for the black population; these constitute the number of observations for the grouped regressions. Note as well that we use female household headship rather than female family headship; the latter was tested, with no difference in results. We ignore husband-wife differences in education, and assume that most marriages take place within the same, broad, less-than-high-school-education group. 
generosity. ${ }^{9}$ Thus we have a time series of data on female headship rates, male wages, female wages, and welfare benefits for the less-educated population over the period 1968-1996, stratified by birth cohort. Table A1 shows the means of the variables.

We estimate a linearized version of equation 4 on these group means:

$$
\mathrm{F}_{\mathrm{ct}}=\alpha+\beta\left(\mathrm{W}_{\mathrm{f}} / \mathrm{W}_{\mathrm{m}}\right)_{\mathrm{ct}}+\gamma\left(\mathrm{W}_{\mathrm{m}}+\mathrm{W}_{\mathrm{f}}\right)_{\mathrm{ct}}+\delta \mathrm{B}_{\mathrm{t}}+\theta \mathrm{Age}_{\mathrm{ct}}+\varepsilon_{\mathrm{ct}}
$$

for birth cohort $\mathrm{c}$ in year $\mathrm{t}$, where now all variables are means over individuals in a cohort-year (ct) group. The age of the group is the only variable controlled in the regression in addition to wages and benefits.

Equation 5 is extremely parsimonious and does not attempt to account for the many other changes in the social, economic, and policy environment that occurred over the 1968-1996 period. Some of the other forces omitted have already been mentioned (e.g., sex ratios), but there were also changes in contraceptive technology and the legal environment governing marriage, fertility, and abortion. Policy variables that are particularly important in addition are changes in other aspects of the welfare system (i.e., welfare reform), the Earned Income Tax Credit (EITC), child support enforcement, and the tax penalty to marriage. The aggregate time-series approach here could make very little progress on controlling for these factors because there are only 29 annual observations in the data. The aim of the analysis here is, therefore, not to isolate the effect of welfare benefits in time series from the effects of these and other omitted factors but, more modestly, simply to determine whether the addition of the two wage variables in equation 5 changes the sign or magnitude of the coefficient on $\mathrm{B}$ and hence whether the time-series evidence is consistent with a welfare effect at the simplest level.

\footnotetext{
${ }^{9}$ We use actual benefits rather than guarantee levels because the two are highly correlated. The three-benefit sum equals the sum of the AFDC benefit and the Food Stamp benefit plus .368 of the Medicaid benefit; the .368 adjustment is for the in-kind nature of the Medicaid program. We also test AFDC alone and AFDC plus Food Stamp benefits alone.
} 
We apply generalized least squares (GLS) to equation 5 to adjust for the effect of grouping on sampling variance by using the number of observations in each cell; we assume the existence of a random year component in the error term when making this grouping adjustment. The random year effect is important because the key regressor of interest—-the welfare benefit—varies only over time and not cross-sectionally, and hence implicitly has only 29 degrees of freedom (the number of years in the data) and not the greater degrees of freedom suggested by the number of grouped observations (273 and 218 for the two race groups; see footnote 8). Ignoring the presence of a random year effect could result in seriously understated standard errors on the benefit coefficient. The Appendix discusses the GLS procedure.

Figure 1 shows the mean female headship rate by race taken over women 18-65 in each year of the CPS. As expected, the rate has risen monotonically over time (not shown graphically is the change in the composition of that trend, from divorce and separation in the early period to never-married single mothers in the later period). Figure 2 shows the trends in welfare benefits-AFDC alone (bottom line), AFDC plus Food Stamps (middle line), and AFDC plus Food Stamps plus Medicaid (top line). Benefits rose in the early period, particularly if Food Stamps and Medicaid are included because these programs were being introduced and expanded over that period. Thus the crude correlation between benefits and headship in this period is positive. But after approximately 1976 all benefit series reversed growth or slowed down. AFDC benefits, which fell monotonically after 1976, display a different pattern from benefits that include both Food Stamps and Medicaid, which fell between 1976 and 1982 but then rose again and subsequently fell again. The expansions of Medicaid are primarily responsible for this difference. Even for this more comprehensive measure of the benefit, however, there has been a drastic overall slowdown in growth after 1976, and consequently the crude positive correlation between benefits and headship disappears. 
Figure 1. Female Headship Rates, White and Black Women 18-65

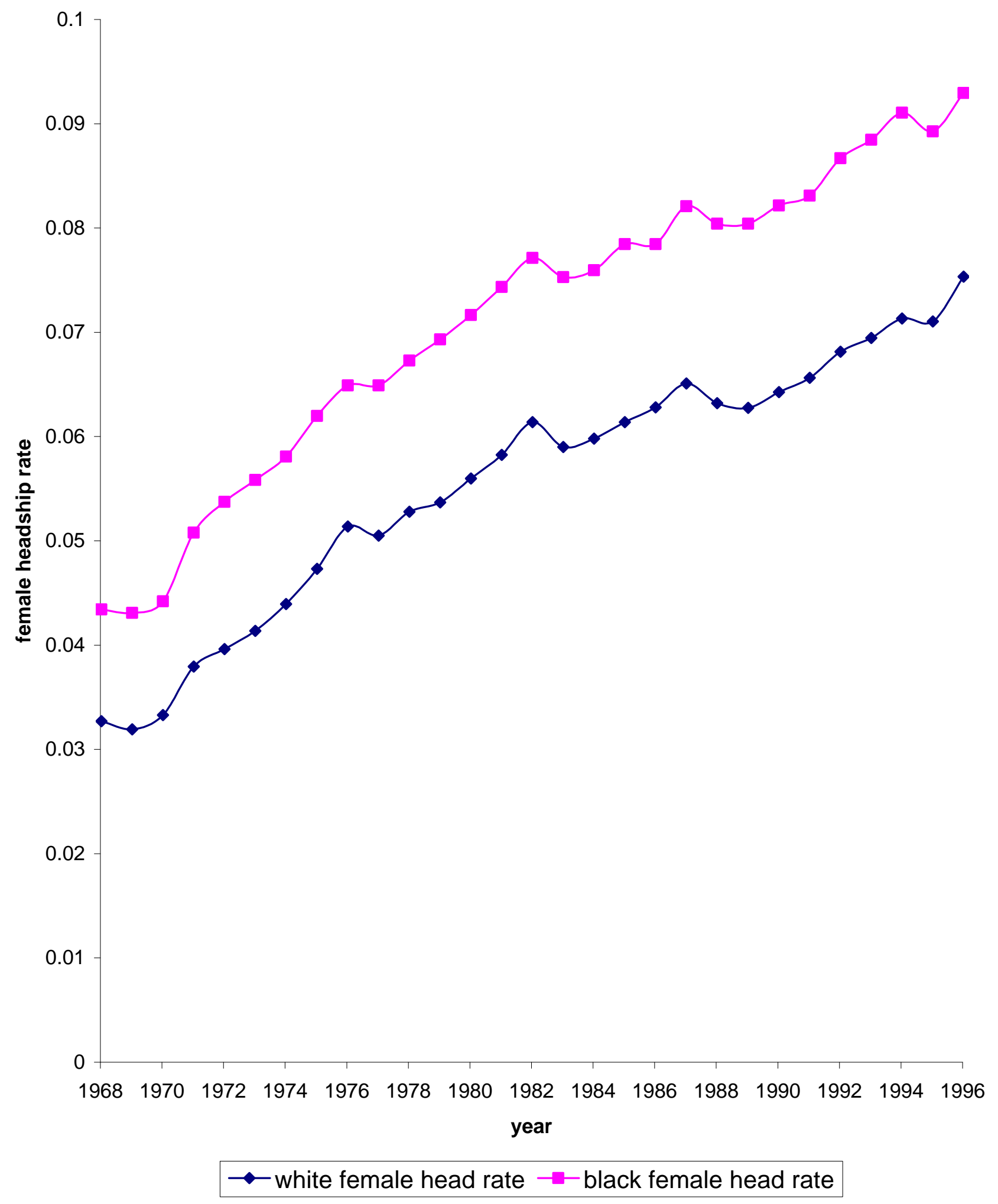


Figure 2. AFDC, Food Stamps, and Medicaid Benefits

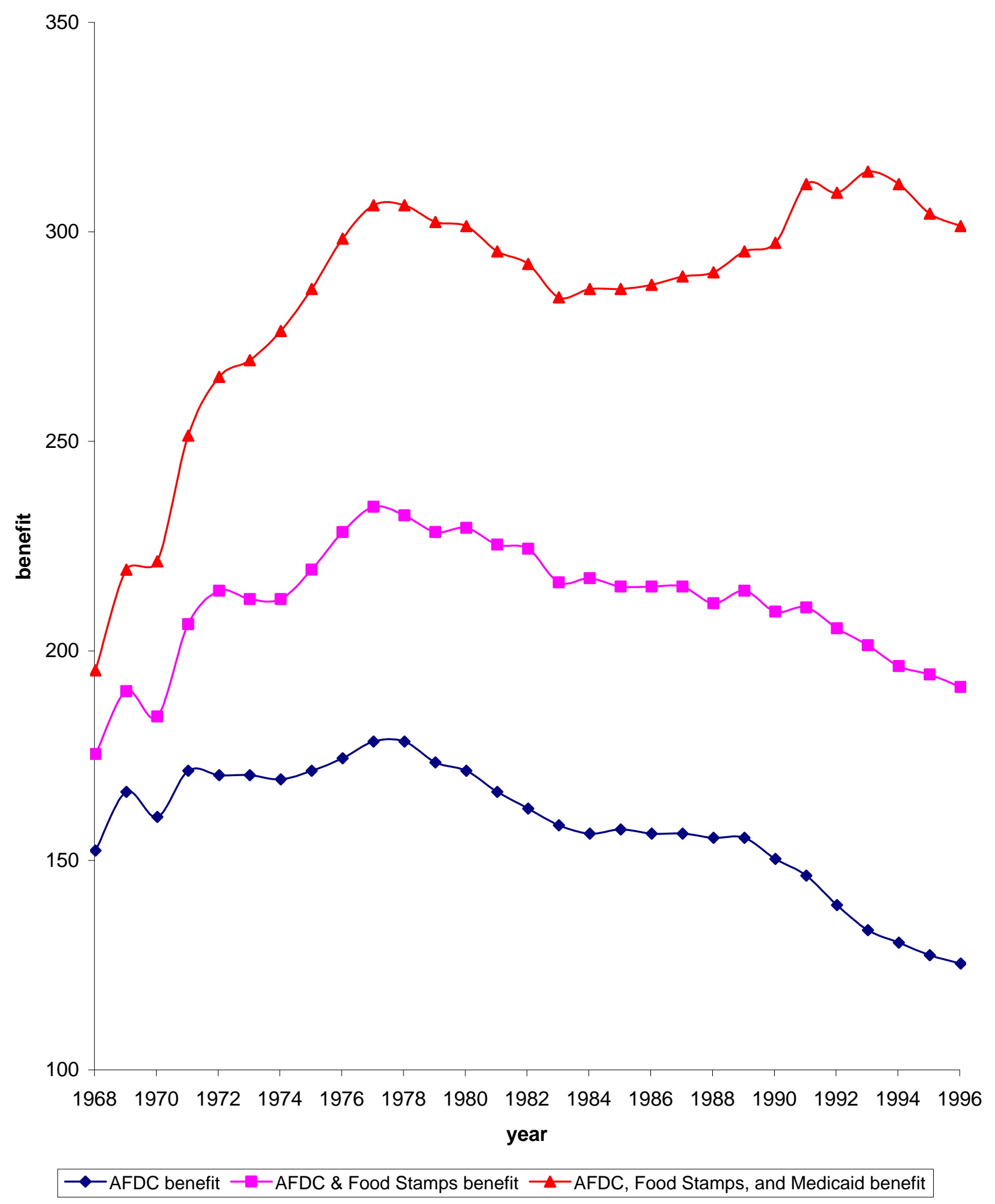


Table 1 confirms these graphical trends with regression results. The table shows the coefficients on $\mathrm{B}_{\mathrm{t}}$ from equation 5 , omitting the wage variables, for different measures of the benefit and for different time periods. Both over all years and over the subperiod from 1976 forward, the AFDC benefit coefficient is negative. When Food Stamps are included, the coefficient is positive overall but negative in the period after 1976. When Medicaid benefits are included, the coefficients are positive in both time frames but weaker and insignificant after 1976.

\section{ESTIMATION RESULTS}

\section{$\underline{\text { White Population }}$}

The results for the white population are prefigured in simple graphical form in Figure 3. The upper three lines of the figure show the life-cycle profiles of female headship for three different birth cohorts (1930-34, 1940-44, and 1950-54) and indicate that headship rates have been rising over time, at least at young ages. The middle three lines in the figure show the life-cycle profiles of female weekly wages for the same three cohorts and indicate, interestingly, extreme stability in that wage. Contrary to the conventional wisdom that female wages have been uniformly rising over time, real wages have not risen over this period for the less-educated population. The lack of growth reflects a general deterioration in the labor market for less-skilled workers over the last 20 years. Clearly, then, the female wage is unlikely to be by itself a strong explanator for the growth in headship for this population.

The three lines in the lower portion of the figure show life-cycle profiles of the female-to-male wage ratio, and here we see growth in the ratio over the three cohorts. Indirectly these results imply, when combined with the lack of a female wage trend, a decline in the level of the real male wage for the less-educated population. This too has been well-documented in the recent literature on the U.S. labor market and contrasts sharply with wages for the more-educated male population, which have been trending strongly upward (e.g., Levy and Murnane, 1992; Katz and Autor, 1999). For present purposes, 
TABLE 1

Regression Coefficients on Welfare Benefits without Wage Variables

\begin{tabular}{lcc}
\hline & All Years & $1976+$ Only \\
\hline AFDC Benefit & $-1.000^{*}$ & $-0.702^{*}$ \\
& $(0.112)$ & $(0.073)$ \\
AFDC+Food Stamp Benefit & $0.342^{*}$ & $-0.909^{*}$ \\
& $(0.130)$ & $(0.096)$ \\
AFDC+Food-Stamp+Medicaid Benefit & & 0.235 \\
& $0.695^{*}$ & $(0.156)$ \\
\hline
\end{tabular}

Notes: Standard errors in parentheses. * designates significance at 10 percent level. All equations are estimated on the white population with less than 12 years of education and all include a fifth-order polynomial in age (the centered age of the birth cohort in each year). All coefficients are multiplied by 1000 . 
Figure 3. Female Headship, Female Wage, and Female-Male Wage Ratio, by Birth Cohort, White Women

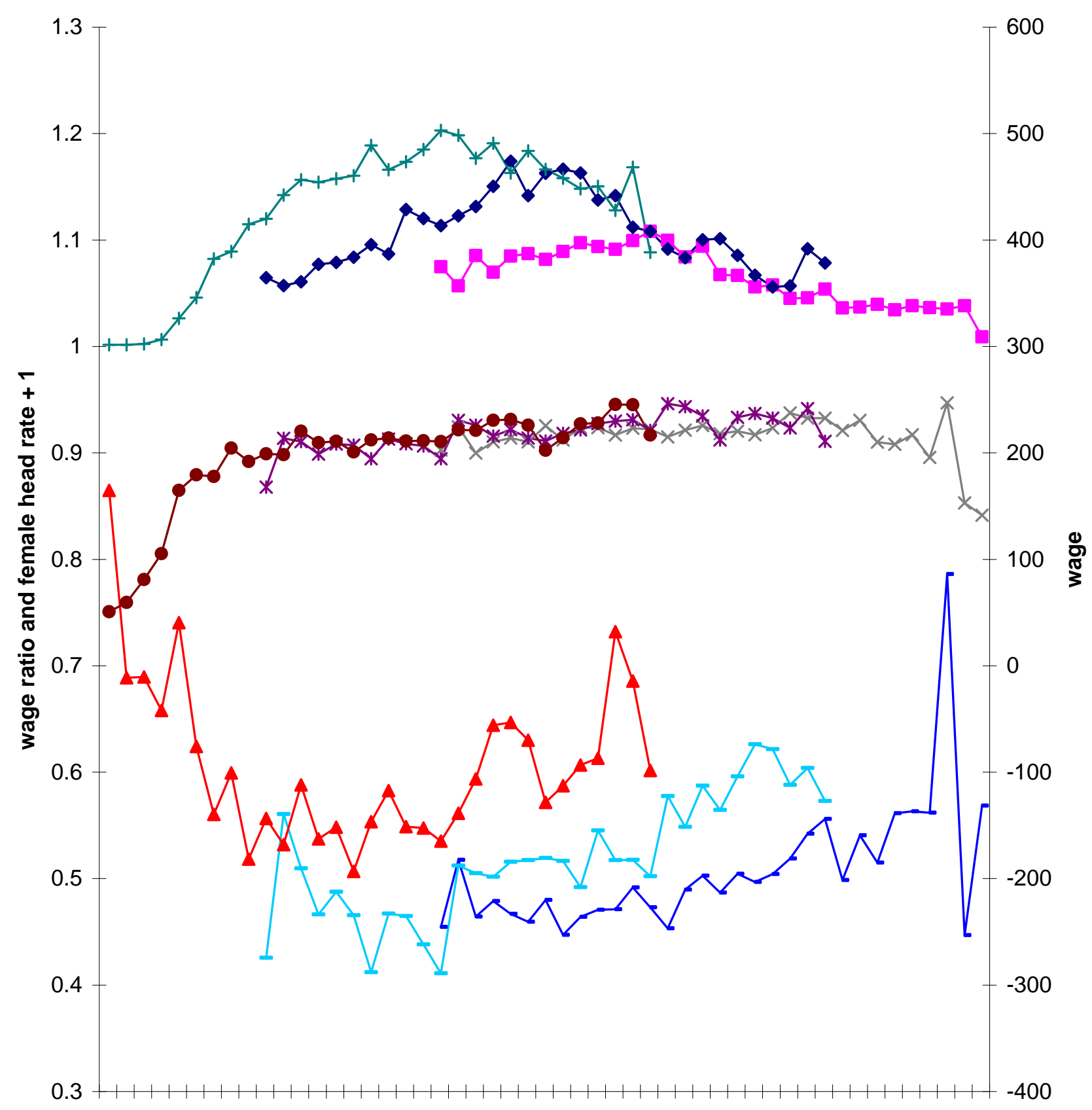

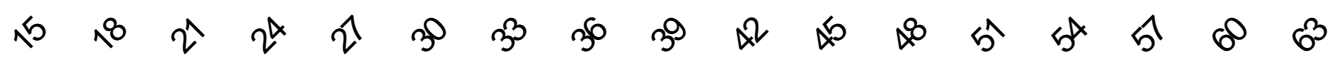
age

\begin{tabular}{|c|c|c|}
\hline $\begin{array}{l}-1930-34 \text { cohort female head rate } \\
--1930-34 \text { cohort female wage ratio } \\
\times-1930-34 \text { cohort wage rate }\end{array}$ & $\begin{array}{l}-\_1940-44 \text { cohort female head rate } \\
--1940-44 \text { cohort female wage ratio } \\
-\leftarrow 1940-44 \text { cohort wage rate }\end{array}$ & $\begin{array}{l}-\leftarrow 1950-54 \text { cohort female head rate } \\
-1950-54 \text { cohort female wage ratio } \\
-1950-54 \text { cohort wage rate }\end{array}$ \\
\hline
\end{tabular}


the rise in the wage ratio implies a reduction in the gains to specialization and division of labor and hence a reduction in the gains to marriage, and this is consistent with the growth of female headship. But it is important to note that it is the result of changes over time in the male wage, not the female wage - that is, it is changes in the male wage that have influenced female headship according to these results.

Finally, although it is not shown in the figure, it follows from the two sets of wage plots that the sum of wages must have fallen (constant female wage, declining male wage), leading to income effects which should also lead to a decline in marriage and an increase in female headship. Thus both wage variables in equation 5 can be seen to have moved in a direction against marriage.

Table 2 shows the results of estimation of several specifications of equation $5 .{ }^{10}$ Column 1 includes only the welfare benefit — the AFDC benefit alone, in this case — and no other variables except age (coefficients not shown). As expected, the AFDC benefit exhibits a significantly negative effect on headship, inconsistent with cross-sectional evidence. However, when the female-male wage ratio is added to the equation, as in column 2, the sign on the AFDC benefit flips around to positive and is statistically significant, though only barely by conventional criteria. The coefficient on the wage ratio itself is positive and significant, as expected from the Figure 3. Column 3 adds the wage sum to the equation, and finds it to have a negative and significant sign, which is consistent with the simple economic model—even holding the ratio of male and female wages fixed, higher levels of wages result in more marriage. The coefficient on the welfare benefit almost doubles when the wage sum is added, a large increase in its magnitude; thus when both "price" and "income" wage effects are controlled, welfare benefits become increasingly consistent with the cross-sectional evidence. Columns 4 and 5 add, in turn, Food Stamp benefits and Medicaid benefits to the welfare-benefit sum; these are more accurate

\footnotetext{
${ }^{10}$ Given the grouped nature of the data, the equation is estimated with least squares rather than with grouped probit or logit.
} 
TABLE 2

Coefficients on Benefit and Wage Variables in Headship Regressions: White Women 18-65, 1968-1996

\begin{tabular}{|c|c|c|c|c|c|}
\hline & (1) & (2) & (3) & (4) & (5) \\
\hline AFDC Benefit & $\begin{array}{l}-1.000 \\
(0.112)\end{array}$ & $\begin{array}{c}0.274 \\
(0.137)\end{array}$ & $\begin{array}{c}0.381 \\
(0.142)\end{array}$ & - & - \\
\hline $\begin{array}{l}\text { AFDC + Food Stamp } \\
\text { Benefit }\end{array}$ & - & - & - & $\begin{array}{c}0.720 \\
(0.086)\end{array}$ & - \\
\hline $\begin{array}{l}\text { AFDC + Food Stamp } \\
+ \text { Medicaid Benefit }\end{array}$ & - & - & - & - & $\begin{array}{c}0.433 \\
(0.048)\end{array}$ \\
\hline $\mathrm{W}_{\mathrm{f}} / \mathrm{W}_{\mathrm{m}}$ & - & $\begin{array}{c}0.389 \\
(0.032)\end{array}$ & $\begin{array}{c}0.344 \\
(0.036)\end{array}$ & $\begin{array}{c}0.283 \\
(0.028)\end{array}$ & $\begin{array}{c}0.167 \\
(0.031)\end{array}$ \\
\hline $\mathrm{W}_{\mathrm{m}}+\mathrm{W}_{\mathrm{f}}$ & - & - & $\begin{array}{l}-0.128 \\
(0.048)\end{array}$ & $\begin{array}{l}-0.175 \\
(0.042)\end{array}$ & $\begin{array}{l}-0.142 \\
(0.041)\end{array}$ \\
\hline
\end{tabular}

Notes: $n=273$. Standard errors in parentheses; all coefficients significant at the 10 percent level. All equations are estimated on the population with less than 12 years of education and all include a fifthorder polynomial in age (the centered age of the birth cohort in each year). All coefficients are multiplied by 1000 except that on the wage ratio. 
representations of what the welfare system offers. Benefit effects are, on average, larger and more positive in this case than for the AFDC benefit alone.

These results constitute the basic findings of the analysis for white women, and will be shown to hold up under a variety of sensitivity tests and alternative formulations. The analysis, as a whole, thus strongly supports the importance of both female and male wages in affecting marriage and female headship decisions.

Table 3 reinforces the importance of including both male and female wages by specifying them in a more conventional linear manner. In column 1 , only the female wage is included, along with the three-benefit sum. The wage coefficient is statistically insignificant, not surprisingly in light of Figure 3. A misleading conclusion would be drawn from this result that female wages do not matter. Column 2 shows that this is not the case when the male wage is entered in addition, which makes the female wage coefficient now positive and significant; the male wage coefficient is negative and significant. ${ }^{11}$ The representation of wage effects in this way rather than as wage ratio and wage sum is fairly arbitrary and a matter of convenience, for they tell the same story —in column 2, an increase in the female wage and a decrease in the male wage (thus holding the sum constant) increases female headship, whereas an increase in both wages in the same amount decreases it, as implied by the fact that -.409 is greater in absolute value than .397 . Finally, columns 3 and 4 replace the benefit sum with year dummies, in one case entering the two wages separately and in the other entering the wage ratio and wage sum; this specification is intended to test whether the specific form of welfare benefits or of other period effects

\footnotetext{
${ }^{11}$ The finding that female headship is a two-variable, not a one-variable, model is quite similar to the celebrated finding of Mincer (1962) that reconciling the cross-sectional and time-series relationship between labor force participation and wages of married women requires the introduction of the wage of the husband.
} 
TABLE 3

Coefficients on Benefit and Wage in Headship Regressions: White Women 18-65, 1968-1996

\begin{tabular}{|c|c|c|c|c|}
\hline & (1) & (2) & (3) & (4) \\
\hline Female Wage & $\begin{array}{c}0.071 \\
(0.131)\end{array}$ & $\begin{array}{c}0.397 \\
(0.106)\end{array}$ & $\begin{array}{c}0.382 \\
(0.111)\end{array}$ & - \\
\hline Male Wage & - & $\begin{array}{c}-.409 \\
(0.032)\end{array}$ & $\begin{array}{l}-0.488 \\
(0.055)\end{array}$ & - \\
\hline $\mathrm{W}_{\mathrm{f}} / \mathrm{W}_{\mathrm{m}}$ & - & - & - & $\begin{array}{c}0.190 \\
(0.039)\end{array}$ \\
\hline $\mathrm{W}_{\mathrm{m}}+\mathrm{W}_{\mathrm{f}}$ & 一 & - & - & $\begin{array}{l}-0.181 \\
(0.045)\end{array}$ \\
\hline $\begin{array}{l}\text { AFDC + Food Stamp + Medicaid } \\
\text { Benefit }\end{array}$ & $\begin{array}{c}0.681 \\
(0.051)\end{array}$ & $\begin{array}{c}0.421 \\
(0.046)\end{array}$ & - & - \\
\hline Year dummies & $\mathrm{n}$ & $\mathrm{n}$ & $\mathrm{y}$ & $\mathrm{y}$ \\
\hline
\end{tabular}

Notes: $\mathrm{n}=273$. Standard errors in parentheses; all coefficients significant at the 10 percent level except that on female wage in column 1. All equations are estimated on the population with less than 12 years of education and all include a fifth-order polynomial in age (the centered age of the birth cohort in each year). All coefficients are multiplied by 1000 except that on the wage ratio. 
matters to the wage results. The answer is that it does not, for the wage coefficients maintain their previous pattern in this case as well. ${ }^{12}$

Another method of testing for the effect of the inclusion of wages on the estimated effect of benefits on headship is to ask whether the model implies that female headship went up more in the late 1970s and 1980s than would have been expected from the influence of wages alone. This is a necessary consequence of the results, for headship did increase over the period and benefits fell, as shown in Figures 1 and 2. To address this question directly, we estimate a model with only the two wage variables - the wage ratio and the wage sum—but without the benefit variable (the age variables are also included). If the interpretation given thus far is correct, the time series of headship rates predicted from this regression should overestimate the actual rate of female headship over the later years of the period.

Figure 4 shows the results graphically. The predicted headship rates from the model display some fluctuation but exhibit an unmistakable upward trend that grows at a faster rate than actual headship, as can be seen from the top two lines in the figure. Although the level of headship is generally underpredicted, it is overpredicted for a few years in the late 1980s and early 1990s. The bottom line in the figure shows the pattern of residuals from the equation (i.e., the difference in the top two lines). The residuals show, correspondingly, a monotonic downward trend (albeit with fluctuation) after around 1974. The residual plot is, indeed, of almost the exact general shape as the plot of AFDC benefits and AFDC plus Food Stamp benefits in Figure 2. Thus, confirming the regression analysis, the inclusion of female and male wages in the model leaves an unexplained gap in actual and predicted female headship that is consistent with the time-series patterns of welfare benefit changes.

\footnotetext{
${ }^{12}$ Some cross-sectional variation still exists in the data arising from the cohort variation (or, holding year fixed, age variation). In a pure time-series analysis, year dummies would absorb all variation and leave nothing for wages. In the year fixed-effects specification in columns 3 and 4, on the other hand, cross-cohort wage differences are correlated with cross-cohort headship differences.
} 
Figure 4. Actual, Predicted, and Residual Female Headship Rate from Models without Benefits, White Women

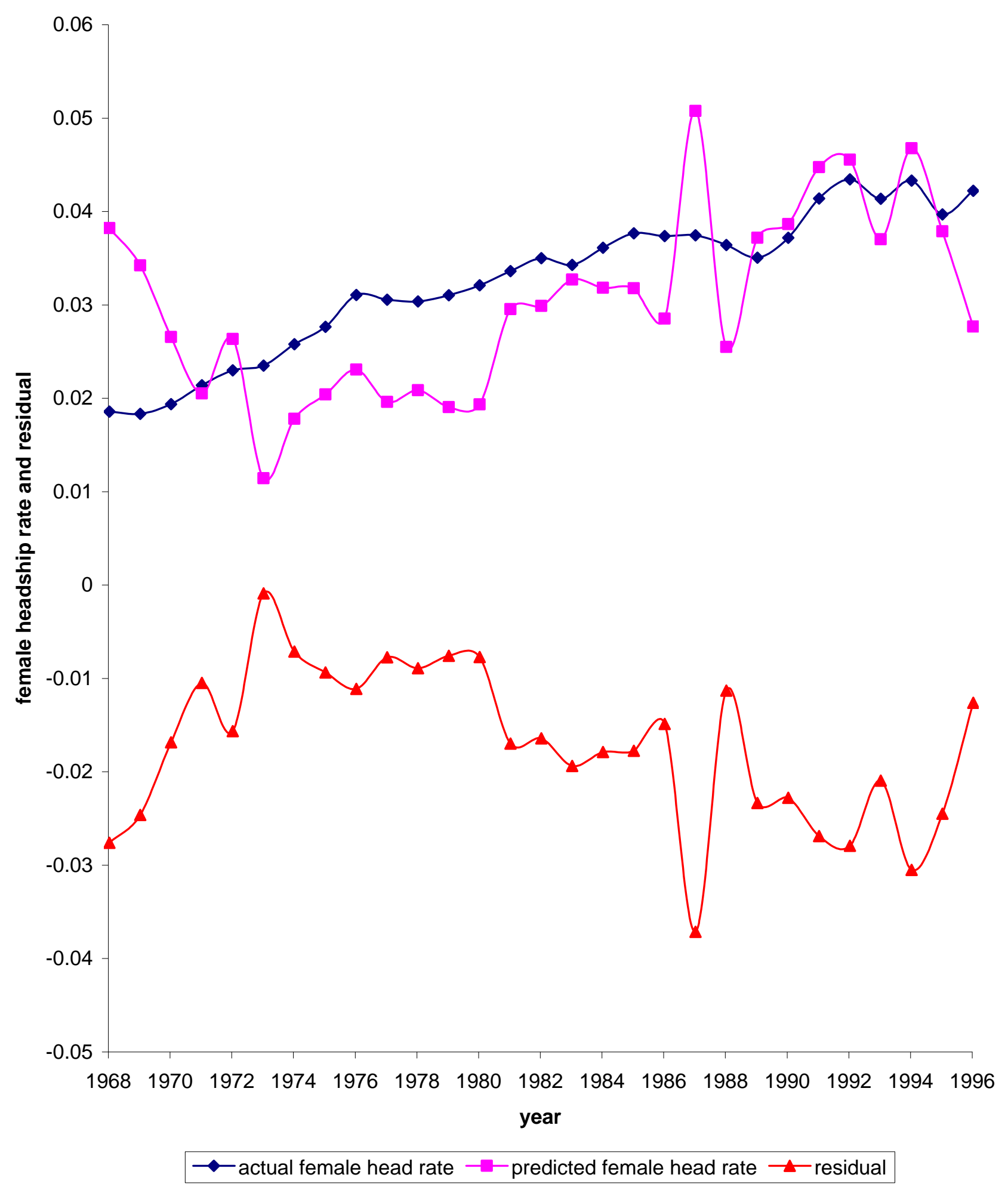


Finally, we conduct three sensitivity tests on the model. The first two examine whether the estimates of benefit effects are stronger among subgroups that are more likely to be affected by welfare benefits and weaker among subgroups that are less likely to be affected by the welfare system. If the effects being estimated are completely spurious and a result of some more general trend, the benefit effects should not vary in the manner to be expected if they are truly reflecting welfare effects. Table 4 shows in its first column the estimates from column 5 in Table 2, as baseline. The second column shows the effect of estimating the equation only on young women, who are the most likely to be welfare recipients and hence to respond; indeed, the welfare benefit coefficient grows larger for this group. The third column shows estimates on the sample of women with education greater than high school, who should be expected to respond less to changes in welfare benefits; indeed, the benefit coefficient drops sharply in this case.

The final column tests whether using a selectivity-bias-corrected wage, instead of the wage for workers only, affects the results. Female employment rates have risen over time and this could be expected to artificially lower mean female wages, on the presumption that most women entering the labor market have lower wages than those previously working. Although it is not obvious how this problem might affect benefit coefficients, it should be tested nevertheless. The results show that the benefit coefficients are larger than in the basic model (as are the wage coefficients) but the sign, significance, and order of magnitude are the same. These results are only suggestive, since they rely on identification assumptions that may be in error, but they do provide at least one piece of evidence on the robustness of the benefit results to the problem of selectively missing wages. ${ }^{13}$

\footnotetext{
${ }^{13}$ In a time-series analysis, where no cross-area variation is used, identification of selection effects is difficult. The selectivity effect in the wage equation is identified by the assumption that unemployment affects the probability of working but not wages directly, an assumption based on the research literature on the effects of the business cycle on the real wage which shows that real wages are fairly cyclically insensitive. The wage coefficients in the headship equation are identified by the inclusion of polynomial year effects in the wage equation and not in the headship equation, thus implicitly allowing wage effects to pick up departures from the trends in the other variables in the equation (benefits and age).
} 
TABLE 4

Coefficients on Wage Ratio, Wage Sum, and Benefit Variables in Headship Regressions White Women 18-65, 1968-1996

\begin{tabular}{lcccc}
\hline & Basic & Young Only $^{\mathrm{a}}$ & Education $>12$ & $\begin{array}{c}\text { Selectivity-Bias } \\
\text { Adjusted Wage }^{\mathrm{b}}\end{array}$ \\
\hline $\mathrm{W}_{\mathrm{f}} / \mathrm{W}_{\mathrm{m}}$ & 0.167 & 0.164 & 0.063 & 0.273 \\
& $(0.031)$ & $(0.048)$ & $(0.011)$ & $(0.167)$ \\
& & & & \\
$\mathrm{W}_{\mathrm{m}}+\mathrm{W}_{\mathrm{f}}$ & -0.142 & -0.194 & -0.030 & -0.560 \\
& $(0.041)$ & $(0.069)$ & $(0.010)$ & $(0.269)$ \\
& & & & 0.674 \\
AFDC+Food Stamp & 0.433 & 0.615 & 0.182 & $(0.059)$ \\
\hline
\end{tabular}

Notes: Standard errors in parentheses. All coefficients significant at the 10 perent level. All equations are estimated on the population with less than 12 years of education except column 3, and all include a fifthorder polynomial in age (the centered age of the birth cohort in each year). Wage sum and benefit coefficients multiplied by 1000 .

${ }^{\mathrm{a}}$ Age less than or equal to 40 .

${ }^{\mathrm{b}}$ Unemployment rate identifies selection bias in wage equation; year polynomials identify wage coefficients. 


\section{$\underline{\text { Black Population }}$}

The results for black women will be discussed within the framework and method already illustrated with the results for white women. Figure 5 shows the life course trends in headship, female wages, and the female-male wage ratio for the same three cohorts as in Figure 3 but for black women. Headship has also risen among black women, with the effects concentrated at younger ages (less than 40). Female wage rates have risen slightly for black women but the magnitude of the growth has not been large, and hence is unlikely to provide an explanation by itself for the trend in headship. The change in the female-male wage ratio is, contrary to that of white women, more mixed in its trend. There has been a rise in that ratio for the most recent cohort shown in the figure, at early ages, but the noise in the data renders this trend not completely clearcut. Smoothing over the fluctuations, however, demonstrates that there has been an upward trend in this ratio for black women as for white women. Moreover, the decline in the black male wage that is implied by the combination of the female wage and female-male wage ratios in Figure 5 is particularly strong in the early ages (35 and less), which is also the age range in which headship among the black population has risen the most (see top lines). The age correspondence between these trends is somewhat closer than it was for the white population, for whom male wages have been dropped at ages somewhat later than the ages at which headship has risen (see Figure 3).

The first column of Table 5 shows the results of the basic model for black women. The wage ratio effect has a smaller magnitude than for white women but is still positive and significant. The effect of the wage sum is also negative and significant and of approximately the same magnitude as for white women. However, the benefit coefficient is not only again positive and significant but is much larger than that for the white population, implying a large effect of welfare benefits. This finding is consistent with the higher welfare participation rates in welfare among the black population than among the white (Gottschalk and Moffitt, forthcoming). 
Figure 5. Female Headship, Female Wage, and Female-Male Wage Ratio, by Birth Cohort, Black Women

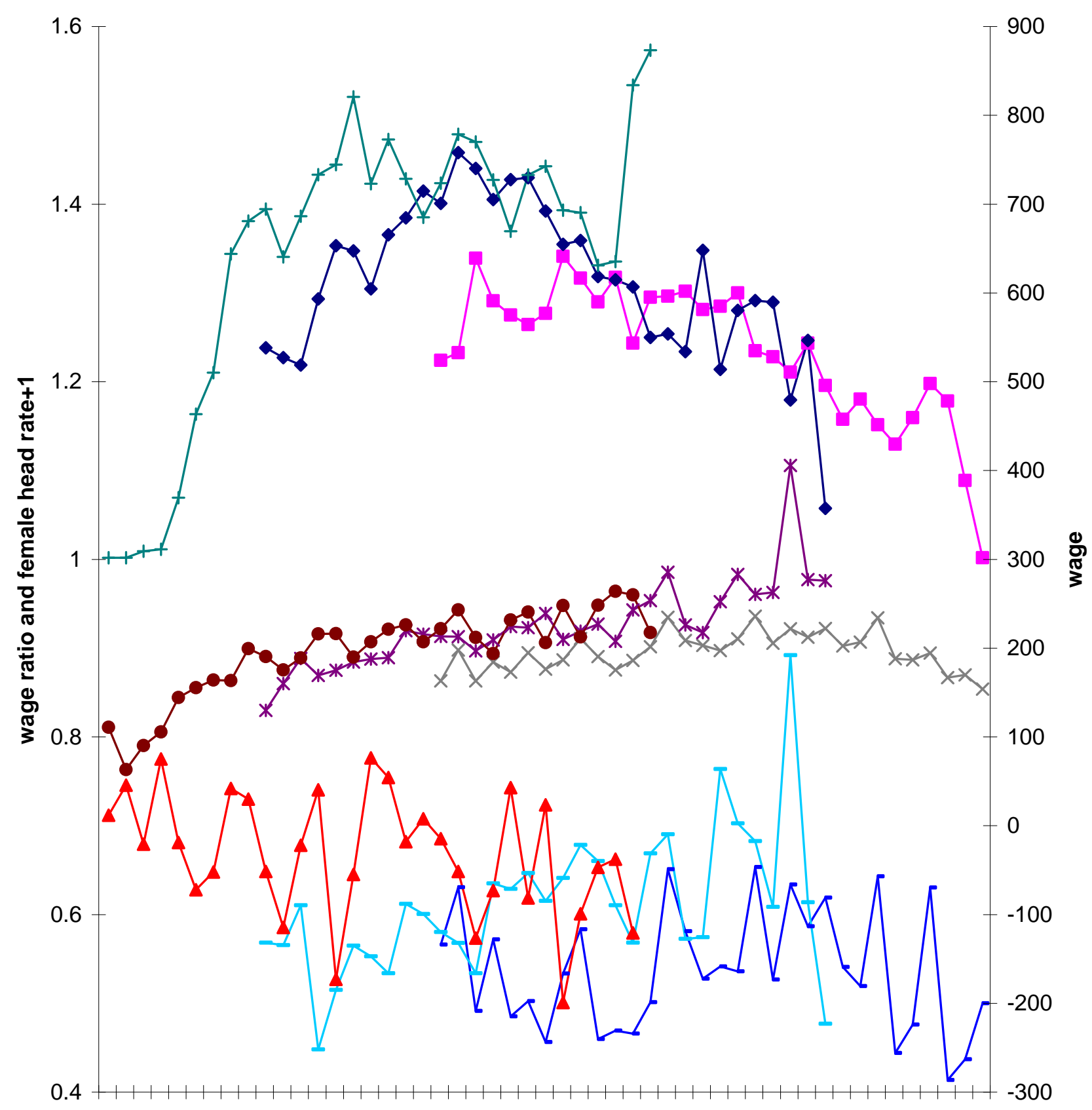

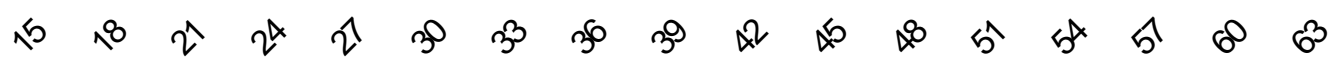
age

\begin{tabular}{|c|c|c|}
\hline $\begin{array}{l}-\longrightarrow \text { 1930-34 cohort female head rate } \\
--1930-34 \text { cohort female wage ratio } \\
\times-1930-34 \text { cohort wage rate }\end{array}$ & $\begin{array}{l}-\_1940-44 \text { cohort female head rate } \\
--1940-44 \text { cohort female wage ratio } \\
-\leftarrow 1940-44 \text { cohort wage rate }\end{array}$ & $\begin{array}{l}-1 \text { 1950-54 cohort female head rate } \\
-1950-54 \text { cohort female wage ratio } \\
\longrightarrow-1950-54 \text { cohort wage rate }\end{array}$ \\
\hline
\end{tabular}


TABLE 5

Coefficients on Wage Ratio, Wage Sum, and Benefit Variables in Headship Regressions Black Women 18-65, 1968-1996

\begin{tabular}{lccc}
\hline & Basic & Young Only $^{\mathrm{a}}$ & Education $>12$ \\
\hline $\mathrm{W}_{\mathrm{f}} / \mathrm{W}_{\mathrm{m}}$ & 0.096 & 0.069 & 0.059 \\
& $(0.027)$ & $(0.031)$ & $(0.052)$ \\
& & & -0.109 \\
$\mathrm{~W}_{\mathrm{m}}+\mathrm{W}_{\mathrm{f}}$ & -0.170 & -0.253 & $(0.077)$ \\
& $(0.067)$ & $(0.105)$ & 0.576 \\
AFDC+Food Stamp + & 1.160 & 1.520 & $(0.300)$ \\
Medicaid Benefit & $(0.117)$ & $(0.154)$ & \\
\hline
\end{tabular}

Notes: $n=207$. Standard errors in parentheses. All coefficients significant at the 10 percent level. All equations are estimated on the population with less than 12 years of education except column 3 , and all include a fifth-order polynomial in age (the centered age of the birth cohort in each year). Wage sum and benefit coefficients multiplied by 1000 .

${ }^{\mathrm{a}}$ Age less than or equal to 40 . 
This stronger benefit effect can be seen in Figure 6, where the predicted and actual headship rates from a model without benefits are shown for black women. ${ }^{14}$ The residual plot at the bottom now shows a strong correspondence with the pattern of the AFDC/Food-Stamp/Medicaid plot shown in Figure 2. The residual rose more strongly and later than for whites, all the way through the early 1980 s, and did not fall as strongly or as rapidly thereafter as for whites. This residual plot is still not exactly in correspondence with the welfare benefit plot, but it more closely follows it—at least for the most comprehensive benefit level—-than for whites. This is what leads to the stronger estimated effect for black women.

The rest of the columns in Table 5 show sensitivity testing for the black female results. When the analysis is restricted to younger women, the coefficient on the welfare benefit becomes even more positive than in the basic model. When the analysis is restricted only to more-educated women, the benefit coefficient falls by 50 percent and becomes insignificant. The benefit effects are concentrated in the groups with the highest welfare participation rates, thus militating against the hypothesis that the estimated effects are spurious and the result of general trends.

\section{CONCLUSIONS}

Time-series analysis has been relatively ignored in the literature on the effects of welfare benefits on female headship and nonmarital fertility. The relatively low number of degrees of freedom and the plethora of competing explanations from multiple changes in the market and society in time series make estimation with cross-sectional data naturally more attractive, and hence cross-sectional analysis should and will no doubt continue as the dominant mode of research. However, the time-series trend in female headship has dominated most public discussions of welfare effects and it is therefore important to

\footnotetext{
${ }^{14}$ Because of small sample sizes, the year-by-year plots show considerable fluctuation, making the figure difficult to view. The lines have therefore been smoothed for this group.
} 
Figure 6. Actual, Predicted, and Residual Female Headship Rate from Models without Benefits, Black Women

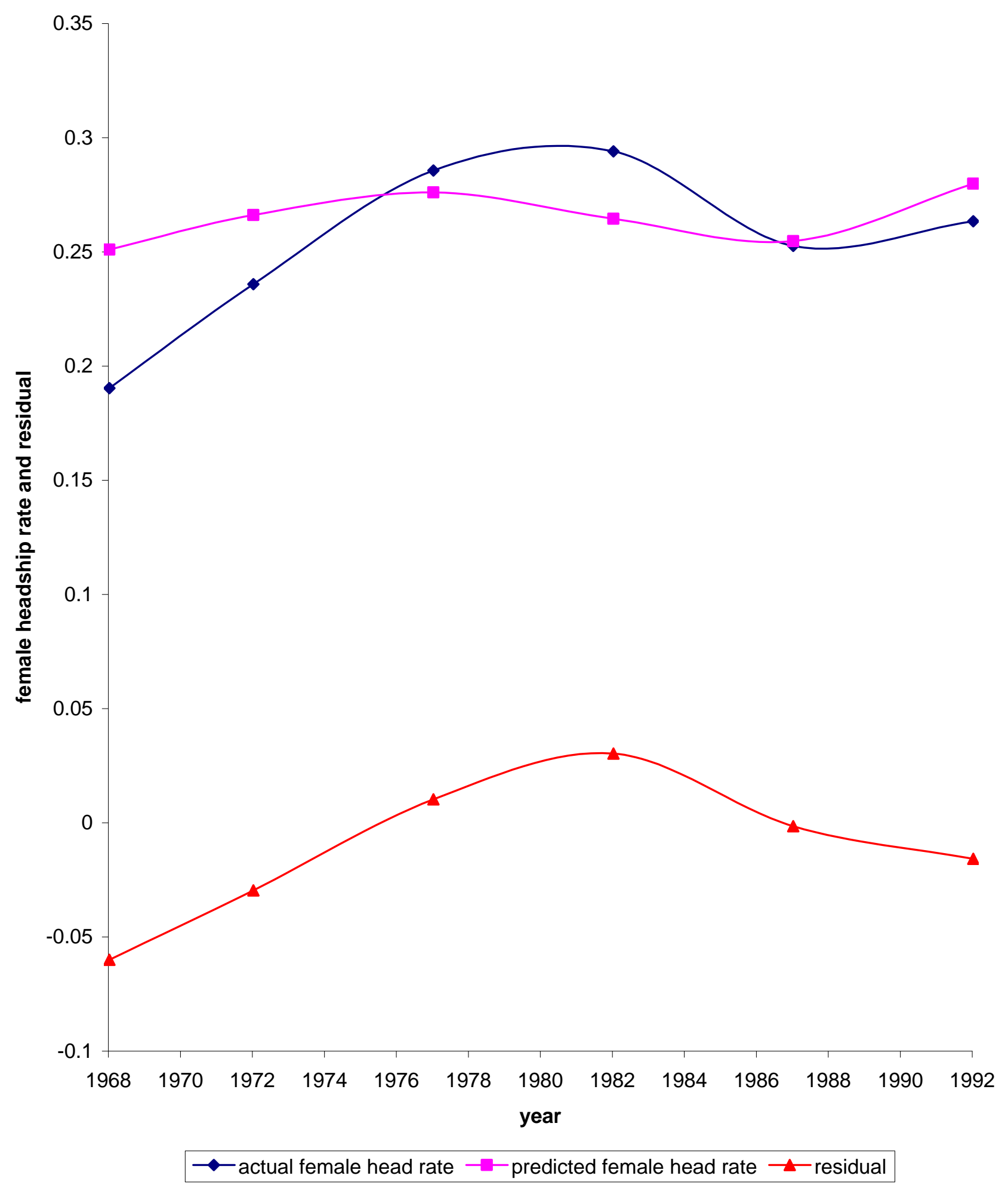


establish a possible explanation for that trend which is consistent with the cross-sectional evidence and which allows both benefits and other factors to play a role.

This analysis has focused exclusively on the capability of male and female wage rates to provide, on their own and ignoring all other time-series factors, an explanation for the upward trend in headship and for the inconsistency in unadjusted benefit-headship correlations between the two types of data. The results for both the white and black less-educated populations show that wages can provide such an explanation, in the sense that when both female and male wages are controlled in a time-series headship regression, there is an unexplained residual that follows roughly the same time-series pattern as that of welfare benefits. Other time-series variables besides welfare benefits may follow this trend; however, the analysis is nevertheless consistent with benefits having played a role. Even without assigning benefits as the major factor in explaining the residual, however, the results strongly suggest that labor market factors rather than governmental policy may have been responsible for the secular rise in female headship in the United States over the last 30 years. 



\section{APPENDIX \\ Generalized Least Squares (GLS) Procedure}

The assumed model is

$$
\begin{gathered}
y_{\text {igt }}=X_{\text {igt }} \beta+\epsilon_{\text {igt }} \\
\epsilon_{\text {igt }}=\mu_{\mathrm{t}}+v_{\text {igt }}
\end{gathered}
$$

for individual $i$ in cohort-year group gt. We assume $E\left(\mu_{t}\right)=E\left(v_{\text {igt }}\right)=E\left(\mu_{t} v_{\text {igt }}\right)=0$ and $E\left(\mu_{t}^{2}\right)=\sigma_{\mu}^{2}$ and $\mathrm{E}\left(\mathrm{v}_{\mathrm{igt}}^{2}\right)=\sigma_{\mathrm{v}^{2}}$. As noted in the text, one of the regressors (the welfare benefit) varies only over $\mathrm{t}$.

We estimate the model in two stages. First we estimate the grouped regression

$$
\bar{y}_{\mathrm{gt}}=\overline{\mathrm{X}}_{\mathrm{gt}} \beta+\bar{\epsilon}_{\mathrm{gt}}
$$

where the bars denote means taken over i within a gt group, by ordinary least squares (OLS) to produce the coefficient estimate $b_{\text {ols }}$. We use the microdata for each i to compute residuals

$$
\mathrm{e}_{\mathrm{igt}}=\mathrm{Y}_{\mathrm{igt}}-\mathrm{X}_{\mathrm{igt}} \mathrm{b}_{\mathrm{ols}}
$$

and we then estimate the variance components using the formulas

$$
\begin{gathered}
\hat{\sigma}_{\mathrm{v}}^{2}=\frac{1}{\mathrm{M}} \sum_{\mathrm{g}} \sum_{\mathrm{t}}\left\{\left[\frac{1}{\mathrm{n}_{\mathrm{gt}}-1} \sum_{\mathrm{i}}\left(\mathrm{e}_{\mathrm{igt}}-\overline{\mathrm{e}}_{\mathrm{gt}}\right)^{2}\right] \frac{\mathrm{n}_{\mathrm{gt}}}{\mathrm{n}_{\mathrm{gt}}-1}\right\}\left(\frac{\mathrm{N}-\mathrm{M}}{\mathrm{N}-\mathrm{M}-\mathrm{K}}\right) \\
\hat{\sigma}_{\mu}^{2}=\left\{\frac{1}{\mathrm{M}-1} \sum_{\mathrm{g}} \sum_{\mathrm{t}}\left(\overline{\mathrm{e}}_{\mathrm{gt}}-\overline{\mathrm{e}}\right)^{2}\right\}\left(\frac{\mathrm{M}-1}{\mathrm{M}-\mathrm{K}-1}\right)-\frac{\hat{\sigma}_{\mathrm{v}}^{2}}{\overline{\mathrm{n}}}
\end{gathered}
$$

where $\mathrm{M}$ is the number of gt groups, $\mathrm{n}_{\mathrm{gt}}$ is the number of observations in group gt, $\mathrm{N}$ is the grand sample size, $\mathrm{K}$ is the number of regressors, and $\overline{\mathrm{n}}$ is the unweighted average of the $\mathrm{n}_{\mathrm{gt}}$. Equation A-5 estimates the variance of the within component as the unweighted average of the estimated within variances for each of the gt groups, with a degrees-of-freedom adjustment. Equation A-6 estimates the variance of the 
between component in the traditional way by subtracting the variance of the mean of the within component from the between variance of the residuals. The average group sample size is used to scale down the within variance.

In the second stage, recognizing that the variance of the error term in A-3 is

$$
\sigma_{\mu}^{2}+\left[\sigma_{v}^{2} / n_{g t}\right]
$$

we reestimate A-3 with weighted least squares using the inverse of the square root of the estimates of this variance as weights and using the estimates of the two error component variances obtained from the individual data to estimate the variance in A-7.

As Dickens (1990) has noted, if $\mathrm{n}_{\mathrm{gt}}$ and $\sigma_{\mu}^{2}$ are sufficiently large, the variance of the error term in A-3 is essentially homoskedastic and hence the GLS procedure will not produce standard errors very different from those of OLS. Our estimates of GLS and OLS standard errors turned out to be extremely close to one another, and this appears to be the reason (large cell sample sizes and relatively large random component variances). 
TABLE A1

Means of the Variables in the Analysis

\begin{tabular}{|c|c|c|c|c|c|c|c|c|}
\hline & \multicolumn{4}{|c|}{ White Women } & \multicolumn{4}{|c|}{ Black Women } \\
\hline & Mean & $\begin{array}{l}\text { Standard } \\
\text { Deviation }\end{array}$ & Minimum & Maximum & Mean & $\begin{array}{l}\text { Standard } \\
\text { Deviation }\end{array}$ & Minimum & Maximum \\
\hline Female Headship (F) & 0.096 & 0.058 & 0.001 & 0.217 & 0.253 & 0.123 & 0.008 & 0.506 \\
\hline Female Weekly Wage $\left(\mathrm{W}_{\mathrm{f}}\right)$ & 201 & 35 & 71 & 253 & 183 & 41 & 78 & 307 \\
\hline Male Weekly Wage $\left(\mathrm{W}_{\mathrm{m}}\right)$ & 375 & 91 & 88 & 504 & 317 & 77 & 86 & 425 \\
\hline $\mathrm{W}_{\mathrm{f}} / \mathrm{W}_{\mathrm{m}}$ & 0.555 & 0.088 & 0.410 & 0.871 & 0.604 & 0.160 & 0.384 & 1.859 \\
\hline $\mathrm{W}_{\mathrm{m}}+\mathrm{W}_{\mathrm{f}}$ & 577 & 123 & 161 & 732 & 500 & 108 & 165 & 706 \\
\hline AFDC Benefit & 158 & 15 & 125 & 178 & 164 & 9 & 139 & 178 \\
\hline AFDC+Food Stamp Benefit & 211 & 14 & 175 & 234 & 214 & 15 & 175 & 234 \\
\hline $\begin{array}{l}\text { AFDC+Food Stamp+ } \\
\text { Medicaid Benefit }\end{array}$ & 284 & 29 & 195 & 314 & 278 & 30 & 195 & 311 \\
\hline
\end{tabular}

Notes: $\mathrm{n}=273$ for white women, 207 for black women. Population includes all women with less than 12 years schooling and in cohort-year cells with at least 100 observations. All wage and benefit figures in 1992 constant dollars. All welfare benefits are monthly. 



\section{References}

Becker, G. 1960. “An Economic Analysis of Fertility.” In Demographic and Economic Change in Developed Countries. Universities-National Bureau Committee for Economic Research, Special Conference Series, no. 11. Princeton, NJ: Princeton University Press.

Becker, G. 1965. “A Theory of the Allocation of Time.” Economic Journal 75: 493-517.

Becker, G. 1973. “A Theory of Marriage.” In The Economics of the Family, edited by T. W. Schultz. Chicago: University of Chicago Press.

Becker, G. 1981. A Treatise on the Family. Cambridge: Harvard University Press.

Becker, G., and H. G. Lewis. 1973. "Interaction Between Quantity and Quality of Children." In The Economics of the Family, edited by T. W. Schultz. Chicago: University of Chicago Press.

Danziger, S., G. Jakubson, S. Schwartz, and E. Smolensky. 1982. "Work and Welfare as Determinants of Female Poverty and Household Headship." Quarterly Journal of Economics 97: 519-534.

Dickens, W. 1990. "Error Components in Grouped Data: Is It Ever Worth Weighting?" Review of Economics and Statistics 72: 328-333.

Gottschalk, P., and R. Moffitt. Forthcoming. "Ethnic and Racial Differences in Welfare Receipt in the United States." In American Becoming: Racial Trends and Their Consequences, edited by N. Smelser, W. J. Wilson, and F. Mitchell. Washington, DC: National Academy Press.

Hoffman, S., and G. Duncan. 1988. "A Comparison of Choice-Based Multinomial and Nested Logit Models: The Family Structure and Welfare Use Decisions of Divorced or Separated Women." Journal of Human Resources 23: 550-562.

Hotz, V. Joseph, Jacob Klerman, and Robert Willis. 1997. "The Economics of Fertility in Developed Countries: A Survey." In Handbook of Population and Family Economics, edited by M. Rosenzweig and O. Stark. New York: Elsevier North-Holland.

Katz, L., and D. Autor. 1999. "Changes in the Wage Structure and Earnings Inequality." In Handbook of Labor Economics, vol. 3A, edited by O. Ashenfelter and D. Card. New York: North Holland.

Levy, F., and R. Murnane. 1992. "U.S. Earnings Levels and Earnings Inequality: A Review of Recent Trends and Proposed Explanations." Journal of Economic Literature 30: 1333-1381.

Lichter, D., F. LeClere, and D. McLaughlin. 1991. "Local Marriage Markets and the Marital Behavior of Black and White Women." American Journal of Sociology 96: 843-867.

Lichter, D., D. McLaughlin, and D. Ribar. 1997. "Welfare and the Rise of Female Headed Families." American Journal of Sociology 103: 112-143. 
Mincer, J. 1962. "Labor Force Participation of Married Women: A Study of Labor Supply." In Aspects of Labor Economics, Universities-National Bureau Committee for Economic Research, Special Conference Series, no. 14. Princeton, NJ: Princeton University Press.

Moffitt, R. 1998. "The Effect of Welfare on Marriage and Fertility.” In Welfare, the Family, and Reproductive Behavior, edited by R. Moffitt. Washington, DC: National Academy Press.

Smith, H., S. P. Morgan, and T. Koropeckyj-Cox. 1996. "A Decomposition of Trends in the Nonmarital Fertility Ratios of Blacks and Whites in the United States, 1960-1992." Demography 33: 141-151.

Weiss, Y. 1997. "The Formation and Dissolution of Families: Why Marry? Who Marries Whom? And What Happens Upon Divorce?" In Handbook of Population and Family Economics, edited by M. Rosenzweig and O. Stark. New York: Elsevier North-Holland.

Willis, R. 1973. "Economic Theory of Fertility Behavior." In The Economics of the Family, edited by T. W. Schultz. Chicago: University of Chicago Press.

Wilson, W. J. 1987. The Truly Disadvantaged. Chicago: University of Chicago Press.

Wilson, W. J., and K. Neckerman. 1986. "Poverty and Family Structure: The Widening Gap between Evidence and Public Policy Issues." In Fighting Poverty, edited by S. Danziger and D. Weinberg. Cambridge, MA: Harvard University Press. 